Animal Morphophysiology

Received on: 05/08/2020

Accepted on: 30/09/2020

\title{
Influence of season and external morphology on thermal comfort and physiological responses in bulls from two breeds adapted to a subtropical climate
}

Influência da estação e da morfologia externa no conforto térmico e respostas

fisiológicas em touros de duas raças adaptadas a um clima subtropical

${ }^{1}$ SOUTO, Paula Lorena Grangeira

https://orcid.org/0000-0002-2150-8239

${ }^{2}$ BARBOSA, Eleonara Araújo

https://orcid.org/0000-0002-3813-5272

${ }^{3}$ MARTINS, Edison

https://orcid.org/0000-0002-8269-1727

\author{
${ }^{3}$ MARTINS, Vera Maria Villamil \\ https://orcid.org/0000-0003-2294-8540 \\ ${ }^{4}$ HATAMOTO-ZERVOUDAKIS, Luciana \\ Keiko \\ https://orcid.org/0000-0001-6030-096X \\ 2*PIMENTEL, Concepta Margaret \\ Mcmanus \\ https://orcid.org/0000-0002-1106-8962 \\ ${ }^{2}$ RAMOS, Alexandre Floriani \\ https://orcid.org/0000-0002-9668-8529
}

\begin{abstract}
${ }^{1}$ Universidade de Brasília -UNB- Faculdade de Agronomia e Medicina Veterinária, Brasília/DF, Brazil

${ }^{2}$ Universidade de Brasília -UNB - Instituto de Ciências Biológicas, Brasília/DF Brasília, Brazil ${ }^{3}$ Brazilian Association of Breeders of the Crioulo Lageano Breed - Fazenda Bom Jesus do Herval, Estação Canoas Interior, Ponte Alta/SC, Brazil

${ }^{4}$ Universidade Federal de Mato Grosso - Programa de Pós-Graduação em Ciência Animal, Av. Fernando Corrêa da Costa, n 2367, Boa Esperança, Cuiabá, Campo Grande - Av. Senador Filinto Muller, no 2443, Vila Ipiranga, Caixa Postal 549. CEP 79074-460. Campo Grande/MS, Brazil

* Mail for correspondence: concepta@unb.br
\end{abstract}

\begin{abstract}
Animals in subtropical regions can be exposed to periods of thermal stress. Locally adapted breeds are especially important in this context, but these have little information available in their natural environments. The aim of this study was to assess whether season affects thermal comfort and physiological responses to increased temperatures of two breeds of bulls in a subtropical climate. Four Angus and four Crioulo Lageano bulls were used in this study. Body and testicles measurements, skin pigmentation and thickness, hair number, length and pigmentation, respiratory rate, panting score, rectal temperature and haematological profile were recorded on three occasions in summer and winter, morning and afternoon. The surface temperature of the flank, eye and scrotum were obtained by infrared thermography. Hair coat colour was determined by CIELAB method. Thermal comfort indexes were calculated from meteorological data. Statistical analysis included analyses of variance, correlations and a partial least squares regression
\end{abstract}


in determining which traits were the most important in thermal adaptability. External morphology of the bulls was important for explaining physiological changes in both seasons, but their contribution was greater in summer. Bulls experienced moderate heat stress in summer, which led to significant physiological responses, which were more pronounced in Angus bulls. The main differences in thermal adaptation found between breeds were the hair coat characteristics and respiratory rate. Despite using different mechanisms to cope with environmental challenges, all bulls were able to maintain optimal testicular thermoregulation as well as systemic normothermia throughout the seasons, showing good adaptation to the climate conditions.

Keywords: conservation, reproduction, stress, thermography, thermoregulation.

\section{RESUMO}

Animais em regiões subtropicais podem ser expostos ao estresse térmico. As raças localmente adaptadas são especialmente importantes nesse contexto, mas possuem pouca informação disponível em seus ambientes naturais. O objetivo deste estudo foi avaliar se a estação afeta $o$ conforto térmico e as respostas fisiológicas ao aumento da temperatura de duas raças de touros em clima subtropical. Quatro touros Angus e quatro Crioulo Lageano foram utilizados neste estudo. As medidas do corpo e testículos, pigmentação e espessura da pele, número, comprimento e pigmentação de pêlos, frequência respiratória, escore ofegante, temperatura retal e perfil hematológico foram registradas no verão e inverno, manhã e tarde. A temperatura da superfície do flanco, olho e escroto foi obtida por termografia infravermelho. Os índices de conforto térmico foram calculados a partir de dados meteorológicos. A análise estatística incluiu análises de variância, correlações e uma regressão parcial de mínimos quadrados para determinar quais características foram as mais importantes na adaptabilidade térmica. A morfologia externa dos touros foi importante para explicar as mudanças fisiológicas nas duas estações, mas sua contribuição foi maior no verão. Os touros sofreram estresse térmico moderado no verão, o que levou a respostas fisiológicas significativas, que foram mais pronunciadas na Angus. As principais diferenças de adaptação térmica encontradas entre as raças foram as características do pêlo e a frequência respiratória. Apesar de usar diferentes mecanismos para lidar com os desafios ambientais, todos os touros foram capazes de manter a termorregulação testicular ideal e a normotermia, mostrando boa adaptação às condições climáticas.

Palavras chaves: conservação, reprodução, estresse, termografia, termorregulação.

\section{INTRODUCTION}

The main challenges to be faced in world crop and livestock production by the end of 2050 involve climate and socialeconomic issues (FAO, 2009). While on one hand it will be necessary an increase in food production by $70 \%$ to feed the world, on the other hand, climate change is likely to cause risks for long-term food security, as it can affect the production and survival of animals and crops around the world (FAO, 2009). More extreme weather and climate events are being seen, affecting livestock farming worldwide (Bishop-Williams et al., 2015). Options are available for mitigation of thermal discomfort in farming systems, but they are usually quite expensive, especially in continentsized countries, such as Brazil (RojasDowning et al., 2017).

Livestock products provide approximately $33 \%$ of the protein consumed globally, and climate change may lead to a reduction in average 
carcass weight (FAO, 2015). This could contribute to changes in the criteria for animal selection, as environmental conditions are changing faster than species can adapt. Thus, the inclusion of individuals which are well adapted to the climate in breeding programs should be considered. In addition, locally adapted animals remain essential to many livestock-keeping livelihoods.

Homeothermic animals have a thermoneutral zone, which is a range where the minimum metabolic rate is maintained, and heat production is relatively constant to regulate the core body temperature (Renaudeau et al., 2012). When the environmental conditions are outside of the limit of the thermoneutral zone of the animal a condition known as thermal stress occurs, which in turn prompts behavioural and physiological responses in an attempt to preserve homeostasis (Bernabucci et al., 2010). Ruminant physiology is affected by thermal stress (McManus et al., 2020) and its magnitude can be quantified through formulating discomfort indexes and measuring physiological traits (Dalcin et al., 2016). Unfortunately, many locally adapted breeds are endangered and poorly documented; and some of these genetic resources were even lost before their potential roles in climate change adaptation could be recognized (FAO, 2015).

The aim of this study was to investigate the seasonal effect of climate and animal morphology on thermal comfort and physiological responses in bulls from a locally adapted cattle breed, Crioulo Lageano, in comparison with bulls from an exotic commercial breed, Angus, both raised in southern Brazil.

\section{MATERIAL AND METHODS}

The experiment was conducted during the summer and winter of 2016 in the Southern region of Brazil $\left(27^{\circ} 48^{\prime} 58^{\prime \prime} \mathrm{S}\right.$, $\left.50^{\circ} 19^{\prime} 34^{\prime \prime} \mathrm{W}\right)$, where the mean elevation is $884 \mathrm{~m}$ above sea level. Eight clinically healthy bulls, four adult Angus and four Crioulo Lageano (both Bos taurus taurus), reproductively active, were judged as sound for breeding by previous breeding soundness evaluation. Bulls were raised in a bovine reproduction centre under the same environmental conditions and handling. All bulls in this study were born and raised in the same region where the experiment was performed.

Average, maximum and minimum values for wind speed $(\mathrm{km} / \mathrm{h})$, air temperature $\left({ }^{\circ} \mathrm{C}\right)$ and relative humidity (\%) were recorded by an automated meteorological station of the National Institute of Meteorology - INMET in summer and in winter. Mean radiant temperature of the environment was measured using a black globe, which consists of a matt black painted hollow copper sphere of approximated diameter $15 \mathrm{~cm}$, containing a thermometer bulb fixed at the centre of the sphere, without a source of heat (Alves et al., 2011). The measurements were recorded three times on different days in each season. The temperature-humidity index was calculated in the morning and the afternoon following Thom's formula: $\mathrm{THI}=(0.8 \times \mathrm{Ta})+(\mathrm{RH} /(100) \times(\mathrm{Ta}-$ 14.4) + 46.4), where THI is the temperature-humidity index, $\mathrm{Ta}$ is air temperature $\left({ }^{\circ} \mathrm{C}\right)$ and $\mathrm{RH}$ is the air relative humidity (\%). Another formula (Dalcin et al., 2016) was also used to calculate the temperature and humidity index according to the National Research 
Council's formula: $\mathrm{THI}_{\mathrm{NRC}}=(1.8 \times \mathrm{Ta}+$ $32)-(0.55-0.0055 \times \mathrm{RH}) \times(1.8 \times \mathrm{Ta}-$ 26) Where $\mathrm{THI}_{\mathrm{NRC}}$ is the National Research Council (NRC) temperaturehumidity index, $\mathrm{Ta}$ is air temperature $\left({ }^{\circ} \mathrm{C}\right)$, and $\mathrm{RH}$ is relative humidity $(\%)$.

The Livestock Weather Safety Index uses THI to classify stress level into three categories, as follows: $\mathrm{THI} \leq 78$ are considered as "no stress", THI from 79 to 83 are considered as "danger stress level" and THI $\geq 84$ as "emergency stress level" (LCI, 1970).

\section{Physiological traits and thermal comfort indexes}

Bulls were led to a squeeze chute at 8:00 a.m. and at 03:00 p.m., on three different days in summer and in winter, and after acclimatization physiological traits and thermal comfort indexes were measured. Respiratory rate was measured by counting the thoracoabdominal movements per minute. Rectal temperature $\left({ }^{\circ} \mathrm{C}\right)$ was measured using a veterinary clinical thermometer, and panting score (0-4) was assessed according to the scoring system of Kerr (2015). Blood samples collected through jugular venipuncture into vacuum tubes containing 5\% EDTA were cooled and taken to the laboratory for processing using an automated haematology analyzer (Cell-Dyn ${ }^{\circledR}$ 3700).
Surface temperatures of the flank, eye and scrotum were determined by infrared thermography (FLIR T420-Series ${ }^{\circledR}$ system), and the thermal images were analyzed using FLIR Tools ${ }^{\circledR}$ software (version 5.6.16078.1002) (Figure 1). The difference between line 1 and 2 of Figure 1-C, produced the top-to-bottom temperature gradient of the scrotum. The setting for emissivity was 0.98 for all the images. The reflected temperature was determined using a crumpled and reflattened piece of aluminum foil photographed by the infrared camera (Usamentiaga et al., 2014). Thermal comfort indexes (Seixas et al., 2017) were calculated using the following formulas: Iberia' index $=100$ - $[18$ (RT 38.33)], where $100=$ maximum efficiency in maintaining body temperature below $38.33^{\circ} \mathrm{C} ; 18=$ constant; $\mathrm{RT}=$ mean final rectal temperature; $38.33^{\circ} \mathrm{C}=$ normal mean rectal temperature for cattle. Values closer to 100 indicates better adaptation; Benezra Index $=(\mathrm{RT} / 38.33)+(\mathrm{RR} / 23)$ where, $\mathrm{RT}=$ rectal temperature $\left({ }^{\circ} \mathrm{C}\right) ; \mathrm{RR}$ $=$ respiratory rate per minute; $38.33^{\circ} \mathrm{C}=$ normal mean rectal temperature for cattle; 23 = normal mean respiratory rate for cattle. Values closer to two mean that animals are better adapted (Benezra, 1954).

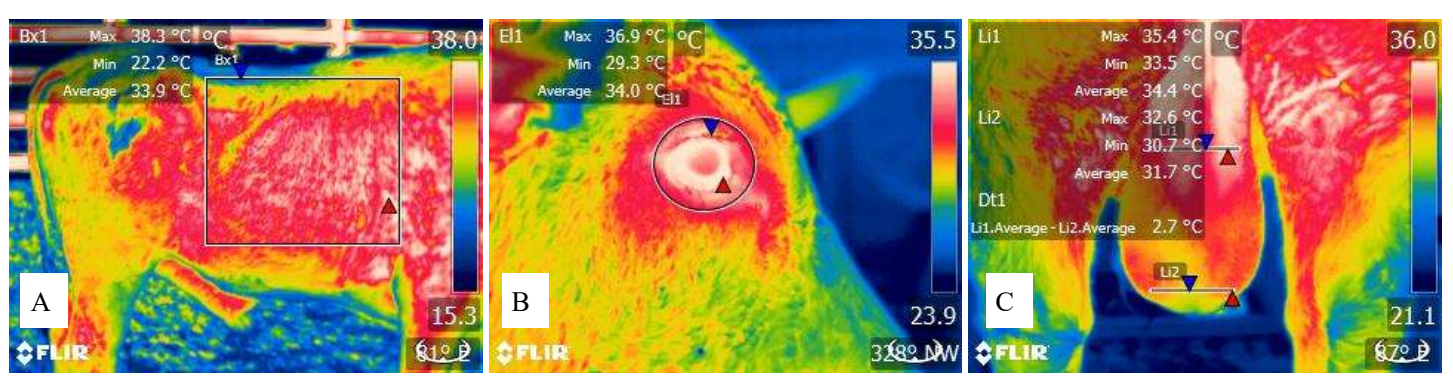

Figure 1. Analysis of surface temperature of the body, in flank region (A), eye (B) and testes (C) by infrared thermography. 
Despite Brazil being a tropical country, in the Southern region where this study was held the winter is usually colder than in other regions. Indices for heat stress have been the subject of more studies than those for cold stress. To better understand whether the bulls had experienced cold stress we used the wind chill index (WCI), which is an index that helps to evaluate cold stress occurrence and intensity. Wind chill represents the 'feels like' temperature and is expressed in temperature-like units. WCI formula was adapted by Tucker et al. (2007) to be used in cold stress research in cattle, as follows: $\mathrm{WCI}=13.12+0.62 \times \mathrm{Ta}-13.17$ $\times(\mathrm{WS})^{0.16}+0.40 \times \mathrm{Ta} \times(\mathrm{WS})^{0.16}$, where $\mathrm{Ta}$ is the air temperature $\left({ }^{\circ} \mathrm{C}\right)$ and WS is the wind speed $(\mathrm{km} / \mathrm{h})$.

Bulls were morphologically characterized by measuring body, testes and coat traits. The body traits were the height at withers, hip height, body length, heart girth, chest depth and cannon bone girth, measured by a hipometer and a tape, and body weight. The formula $\mathrm{TV}=2 \times\left[(\mathrm{TW} / 2)^{\wedge} 2 \times\right.$ $3.14 \times(\mathrm{TL})]$ was used for calculate the testicular volume, where, TV is the testicular volume, TW is the testicular width $(\mathrm{cm})$ and TL is the testicular length (cm). Scrotal circumference was measured by a tape whereas TW, TL and skin thickness of the scrotum were measured by a calliper. Skin thickness of the body was measured by an adipometer, and skin colour was visually determined using a standard scale for bovine skin pigmentation according method describe by Silva (2000). Hair coat colour was measured in triplicate by a spectrophotometer using the CIELAB colour system (Commission internationale de l'éclairage: http://cie.co.at/), which determines the coordinates: *L (brightness), *a (red colour intensity) and ${ }^{*} \mathrm{~b}$ (yellow colour intensity).

To determine the hair coat density and hair coat length, hair samples were taken from the flank area, $30 \mathrm{~cm}$ below the spinal column, using adapted callipers and all hair were counted to give a number of hairs per $\mathrm{cm}^{2}$. The length of the longest ten hairs were measured in each sample (Silva, 2000).

Statistical analyses were performed using the Statistical Analysis System ${ }^{\circledR}$ package (v.9.3, SAS Inc., Cary, NC, USA). A multivariate analysis of variance - MANOVA was carried out to evaluate the effect of season and breed on thermal comfort indexes, body and testicular morphology, on hair coat measurements and the physiological characteristics. Spearman correlations (PROC CORR) were estimated among all variables. Variables that did not present significant correlations with any other traits were removed from the data set, and the original number of variables was reduced. After this first reduction, the model remained with a higher number of variables than the number of observations recorded, and because a standard multivariate analysis does not fit well in this context, a partial least squares regression model (PLS) was chosen due to its capability to maximize explanation of both $\mathrm{x}$ and $\mathrm{y}$ variables, even with a small sample size and nonnormal data, which are characteristics of this data set. A PLS (PROC PLS) was used to study the relationships between one or several response variables (y) (physiological data) with independent variables (x) (climatic data and morphologic measurements) by creating latent variables, also known as factors. This technique solves problems related 
to the high dimensionality of the model and to multicollinearity, i.e., when independent variables are highly correlated with each other, which is the case of this study. An initial model, including season and breed effects, was tested as it was supposed to give more power to the model. However, the effect of the breed became noise in the model and season effect did not add any useful information to the analysis.

The criteria used for dropping the variables from the PLS model were based on the examination of Variable Importance for Projection (VIP) and the patterns and positioning of the variables in the Correlation loading plot (Akarachantachote et al., 2014). The VIP in the PLS procedure is displayed as a variable importance plot that illustrates the contribution of each variable in fitting the PLS model. According to
Wold's criterion, a value less than 0.8 is considered to be "small", which means that the variable is largely uncorrelated with the y response, and indicates that the variable should be removed from the model. Further, another strategy used to optimize the model was checking the squared correlation coefficient among variables. When variables had a very high correlation with another and if they supply redundant information based on their biological function, one of them was removed.

\section{RESULTS AND DISCUSSION}

Regardless of the climatic traits in each season, all values in the afternoon were higher than in the morning, as expected. Except for relative humidity, all traits changed significantly between seasons (Table 1). 
Table 1: Meteorological features and temperature and humidity index in the morning and afternoon during the experimental periods

\begin{tabular}{|c|c|c|c|c|c|}
\hline \multirow[b]{2}{*}{ Morning } & \multicolumn{2}{|c|}{ Summer } & \multicolumn{2}{|c|}{ Winter } & \multirow[b]{2}{*}{ P-value } \\
\hline & Mean & StdDev & Mean & StdDev & \\
\hline \multicolumn{6}{|l|}{ Air temperature $\left({ }^{\circ} \mathrm{C}\right)$} \\
\hline Average mean & 19.48 & 0.88 & 8.79 & 5.76 & $<.0001$ \\
\hline Average high & 20.27 & 1.17 & 8.20 & 5.83 & $<.0001$ \\
\hline Average low & 19.50 & 0.90 & 7.41 & 5.89 & $<.0001$ \\
\hline \multicolumn{6}{|l|}{ Relative humidity (\%) } \\
\hline Average mean & 92.63 & 1.82 & 91.68 & 5.14 & 0.4008 \\
\hline Average high & 89.92 & 2.24 & 89.42 & 6.32 & 0.7164 \\
\hline Average low & 93.13 & 0.92 & 93.08 & 4.61 & 0.9655 \\
\hline Black globe temperature & 23.58 & 2.35 & 5.26 & 2.53 & $<.0001$ \\
\hline THI & 72.15 & 2.24 & 55.64 & 7.45 & $<.0001$ \\
\hline Afternoon & Mean & StdDev & Mean & StdDev & P-value \\
\hline \multicolumn{6}{|l|}{ Air temperature $\left({ }^{\circ} \mathrm{C}\right)$} \\
\hline Average mean & 24.36 & 2.14 & 13.83 & 4.57 & $<.0001$ \\
\hline Average high & 26.45 & 2.13 & 14.15 & 4.34 & $<.0001$ \\
\hline Average low & 24.83 & 2.02 & 12.49 & 4.46 & $<.0001$ \\
\hline \multicolumn{6}{|l|}{ Relative humidity (\%) } \\
\hline Average mean & 72.03 & 8.71 & 66.89 & 15.97 & 0.1727 \\
\hline Average high & 71.71 & 7.05 & 71.01 & 14.18 & 0.8309 \\
\hline Average low & 61.92 & 8.62 & 62.18 & 18.15 & 0.9490 \\
\hline Black globe temperature & 34.81 & 4.28 & 20.04 & 6.00 & $<.0001$ \\
\hline THI & 81.81 & 4.79 & 66.86 & 5.50 & $<.0001$ \\
\hline
\end{tabular}

*StdDev: standard deviation; THI: Temperature and humidity index following Thom's formula.

The THI values in summer indicated that there was moderate heat stress, reaching the 'danger zone' in some periods, but in winter the index was classified as being normal, according Livestock Weather Safety Index (LCI, 1970). Wind speed changed significantly between summer (mean \pm standard deviation of $9.54 \pm 4.83$; ranging from 0.72 to 24.12 $\mathrm{km} / \mathrm{h}$ ) and winter (mean \pm standard deviation of $12.95 \pm 7.88$; ranging from 1.44 to $33.48 \mathrm{~km} / \mathrm{h}$ ). The weather conditions between seasons were quite distinct $(P<0.05)$ with periods of thermal discomfort in summer and some days of frost in winter.

Indices for heat stress have been the subject of more studies than those for cold stress. To better understand if the bulls had experienced cold stress, we 
used the wind chill index (WCI), which is an index that helps to evaluate cold stress occurrence and intensity. The wind chill index (WCI) in winter was $5.38 \pm 6.44$, with a minimum value of 7.97 and a maximum of 16.15. In humans this index is used to estimate the risk of frostbite and hypothermia (Environment Canada, 2014), but for cattle no risk classes in terms of WCI have been validated. Based on Environment Canada's WCI risk classes, the WCI observed in this study is considered to be low for the risk of frostbite, but an increase of thermal discomfort could be expected.

There were significant differences for both effects of breed, season and their interaction on morphological traits (Table 2). The bulls in this study had a body condition score (BCS) of $4.13 \pm 0.69$ and, in general, Angus bulls were heavier but shorter than Crioulo Lageano bulls.

Table 2: Multivariate Analysis of Variance - MANOVA Test Criteria and Exact F Statistics for the Hypothesis of No Overall season, breed and season*breed Effects for morphological traits of Crioulo Lageano and Angus bulls raised in Southern of Brazil

\begin{tabular}{lllllll}
\hline Effect & Statistic & Value & F Value & DF & Den DF & Pr $>$ F \\
\hline Season & Wilks' Lambda & 0.13 & 14.83 & 13 & 30 & $<.0001$ \\
& Pillai's Trace & 0.87 & 14.83 & 13 & 30 & $<.0001$ \\
& Hotelling-Lawley Trace & 6.42 & 14.83 & 13 & 30 & $<.0001$ \\
& Roy's Greatest Root & 6.42 & 14.83 & 13 & 30 & $<.0001$ \\
Breed & Wilks' Lambda & 0.10 & 21.85 & 13 & 30 & $<.0001$ \\
& Pillai's Trace & 0.90 & 21.85 & 13 & 30 & $<.0001$ \\
& Hotelling-Lawley Trace & 9.47 & 21.85 & 13 & 30 & $<.0001$ \\
& Roy's Greatest Root & 9.47 & 21.85 & 13 & 30 & $<.0001$ \\
Season*Breed & Wilks' Lambda & 0.27 & 6.11 & 13 & 30 & $<.0001$ \\
& Pillai's Trace & 0.73 & 6.11 & 13 & 30 & $<.0001$ \\
& Hotelling-Lawley Trace & 2.65 & 6.11 & 13 & 30 & $<.0001$ \\
& Roy's Greatest Root & 2.65 & 6.11 & 13 & 30 & $<.0001$ \\
\hline
\end{tabular}

F Value: $F$ statistic for the given predictor and test statistic; DF: number of degrees of freedom in the model; Den DF: number of degrees of freedom associated with the model errors; $\operatorname{Pr}>\mathrm{F}$ : $\mathrm{p}$ value associated with the $\mathrm{F}$ statistic.

There were no differences in heart girthbody weight ratio between breeds neither summer (Angus, 0.27 \pm 0.06 ; Crioulo Lageano, $0.32 \pm 0.04$ ) nor winter (Angus, $0.31 \pm 0.04$; Crioulo Lageano, $0.32 \pm 0.06$ ), which means that the animals had similar body surface area. Lighter animals usually have larger relative body surface area (Maia et al., 2008), but probably due to the difference in height between breeds they were similar in this measurement. Larger 
animals will have a larger surface area by default. However, smaller animals will usually have a greater surface area to mass ratio and, as a result, more heat loss.

Angus bulls had a significantly darker and longer hair coat, with lower reflectance than Crioulo Lageano bulls in both seasons. Studies have reported the existence of a gene that produces a very short, sleek hair coat in Bos taurus cattle and indicates that the gene locus is most likely on bovine chromosome 20 (Mariasegaram et al., 2007). The authors stated that slicked-haired animals have greater heat tolerance. In this study, only Crioulo Lageano bulls presented this type of hair, although, in winter their hair was longer than in summer, but still significantly shorter than Angus hair.

Hair coat density was similar between breeds in summer, but in winter it was higher in Angus bulls. Both breeds have dark skin, with Angus being slightly darker than Crioulo Lageano. Heat exchange between the animal and environment depends upon body surface area, as well as the hair coat and skin properties. Animals with a small number of hairs per unit area are more favoured in exchanging thermal energy with the environment than those with highdensity hair coats (Silva and Maia, 2011).

The higher coat reflectance, lighter coloured and shorter hair found in Crioulo Lageano bulls certainly favour heat losses by conduction, convection and radiation and these could be important thermoregulatory mechanisms for this breed. However, despite that morphological difference between breeds, no differences were recorded either in skin surface temperatures nor in core body temperatures, which indicate that Angus bulls are likely to use other mechanisms to maintain homeostasis, such as evaporative losses by respiration and sweating. Animals that have dark skin and/or coat tend to have greater heat absorption and may be more susceptible to heat discomfort, but it has been stated that this is compensated by an increased heat loss by cutaneous evaporation (Silva and Maia, 2011). Maia et al. (2008) found that the main way of latent heat dissipation in Holstein cows in a tropical environment is the cutaneous evaporation and as the larger the relative body surface area, the greater heat loss by evaporation.

In general, the physiological responses of the bulls were similar (Table 3). Increasing respiratory rate and hence panting in summer were expected, as evaporative cooling by evaporation of water from the mucous membranes of the respiratory tissues, is one of the most important mechanisms to the dissipation of heat in bovines (Silva, 2000). In cattle, panting score and salivary secretion increase together to promote cooling by evaporation (Reece et al., 2015). In this study, it was noticed that salivation was more intense in Angus bulls, especially in summer afternoon than in Crioulo Lageano bulls. Nonetheless, with regard to the Benezra Index, no differences were found between breeds and the highest values were found in summer afternoons, indicating that bulls experienced some thermal discomfort and had a poor degree of adaptation to heat stress. 
Table 3. Mean \pm standard deviation of physiological traits and thermal comfort indexes per breed in the morning and in the afternoon during the experimental periods

\begin{tabular}{|c|c|c|c|c|}
\hline \multirow{3}{*}{ Variable } & \multicolumn{2}{|l|}{ Summer } & \multicolumn{2}{|l|}{ Winter } \\
\hline & Angus & Crioulo Lageano & Angus & Crioulo Lageano \\
\hline & \multicolumn{4}{|c|}{ Morning temperature $\left({ }^{\circ} \mathrm{C}\right)$} \\
\hline Rectal temp. $\left({ }^{\circ} \mathrm{C}\right)$ & $38.49 \pm 0.62$ & $38.44 \pm 0.27$ & $38.14 \pm 0.52$ & $37.17 \pm 0.81$ \\
\hline Panting score (0-4) & $1.92 \mathrm{a} \pm 0.67 \mathrm{a}$ & $1.08 \pm 0.29 \mathrm{ab}$ & $0.67 \pm 0.65 b c$ & $0.08 \pm 0.29 \mathrm{c}$ \\
\hline Respiratory rate & $49.67 \pm 5.77 \mathrm{a}$ & $30.00 \pm 6.27 b$ & $9.17 \pm 2.69 \mathrm{c}$ & $5.75 \pm 2.45 \mathrm{~d}$ \\
\hline Benezra' index & $3.16 \pm 0.25 \mathrm{a}$ & $2.31 \pm 0.27 \mathrm{ab}$ & $1.39 \pm 0.12 b$ & $1.22 \pm 0.12 b$ \\
\hline Body $\mathrm{ST}^{1}\left({ }^{\circ} \mathrm{C}\right)$ & $35.01 \pm 2.67 \mathrm{a}$ & $33.83 \pm 1.09 \mathrm{a}$ & $27.77 \pm 5.85 \mathrm{~b}$ & $27.40 \pm 5.87 b$ \\
\hline Eye $\mathrm{ST}^{1}\left({ }^{\circ} \mathrm{C}\right)$ & $34.58 \pm 1.50 \mathrm{a}$ & $33.84 \pm 1.33 \mathrm{a}$ & $31.99 \pm 1.49 \mathrm{~b}$ & $30.92 \pm 1.76 b$ \\
\hline Scrotal $\mathrm{ST}^{1}\left({ }^{\circ} \mathrm{C}\right)$ & $32.36 \pm 0.84 \mathrm{a}$ & $32.08 \pm 1.36 \mathrm{a}$ & $28.99 \pm 1.1 \mathrm{ab}$ & $27.54 \pm 3.09 b$ \\
\hline Iberia's index & $85.69 \pm 12.19 \mathrm{c}$ & $94.54 \pm 6.79 b$ & $100.24 \pm 7.71 \mathrm{ab}$ & $105.64 \pm 15.73 \mathrm{a}$ \\
\hline \multirow[t]{2}{*}{$\operatorname{GSM}\left({ }^{\circ} \mathrm{C}\right)$} & $1.71 \pm 1.21 \mathrm{c}$ & $2.30 \pm 0.94 \mathrm{c}$ & $7.24 \pm 3.22 \mathrm{a}$ & $3.92 \pm 1.47 \mathrm{~b}$ \\
\hline & \multicolumn{4}{|c|}{ Afternoon temperature $\left({ }^{\circ} \mathrm{C}\right)$} \\
\hline Rectal temp. $\left({ }^{\circ} \mathrm{C}\right)$ & $39.13 \pm 0.68$ & $38.63 \pm 0.38$ & $38.32 \pm 0.43$ & $38.02 \pm 0.87$ \\
\hline Panting score (0-4) & $2.33 \pm 0.78 \mathrm{a}$ & $1.5 \pm 0.52 \mathrm{a}$ & $0.50 \pm 0.67 \mathrm{~b}$ & $0.08 \pm 0.29 \mathrm{~b}$ \\
\hline Respiratory rate & $66.00 \pm 19.63 a$ & $33.33 \pm 8.41 \mathrm{~b}$ & $9.58 \pm 3.03 \mathrm{c}$ & $5.92 \pm 2.64 \mathrm{~d}$ \\
\hline Benezra's index & $3.89 \pm 0.86 \mathrm{a}$ & $2.46 \pm 0.36 \mathrm{ab}$ & $1.42 \pm 0.14 \mathrm{bc}$ & $1.25 \pm 0.13 \mathrm{c}$ \\
\hline Body ST ${ }^{1}\left({ }^{\circ} \mathrm{C}\right)$ & $36.17 \pm 2.78 \mathrm{a}$ & $35.94 \pm 2.35 \mathrm{a}$ & $26.53 \pm 6.05 b$ & $27.72 \pm 5.64 b$ \\
\hline Eye $\mathrm{ST}^{1}\left({ }^{\circ} \mathrm{C}\right)$ & $36.10 \pm 1.21 \mathrm{a}$ & $35.85 \pm 1.24 \mathrm{a}$ & $33.07 \pm 1.9 \mathrm{~b}$ & $32.10 \pm 1.64 b$ \\
\hline Scrotal $\mathrm{ST}^{1}\left({ }^{\circ} \mathrm{C}\right)$ & $33.45 \pm 1.04$ & $33.38 \pm 1.60$ & $30.51 \pm 1.26$ & $30.05 \pm 2.72$ \\
\hline Iberia' index & $97.09 \pm 11.11 \mathrm{~b}$ & $97.99 \pm 4.94 b$ & $103.39 \pm 9.45 b$ & $120.94 \pm 14.57 \mathrm{a}$ \\
\hline $\operatorname{GSA}\left({ }^{\circ} \mathrm{C}\right)$ & $1.08 \pm 1.07 \mathrm{c}$ & $0.97 \pm 0.70 \mathrm{c}$ & $5.88 \pm 1.98 \mathrm{a}$ & $3.02 \pm 1.67 \mathrm{~b}$ \\
\hline
\end{tabular}

GSM: Gradient temperature from the top to the bottom of the scrotum in the morning. GSA: Gradient temperature from the top to the bottom of the scrotum in the afternoon. ST: surface temperature. ${ }^{1} \mathrm{By}$ infrared thermography. Means with different subscripts in the row are significantly different at $\mathrm{P}<0.05$.

The Iberia index was significantly different in summer morning and winter afternoons, but the differences were only found in one of the periods of the day. In addition, this index did not show strong correlations with the physiological measurements, which led us to assume that Iberia index was not a good adaptability indicator to be used in this study.

Body surface temperature and eye surface temperature were similar for both breeds within the same season, but they were significantly lower in winter. These seasonal differences were also found by Menegassi et al. (2015) in a study with Bradford bulls. When the 
surface temperature exceeds $35^{\circ} \mathrm{C}$ it was more difficult for cattle to dissipate heat and maintain homeostasis (Bernabucci et al., 2010). The thermal gradient between animal surface and ambient temperature is also important for heat dissipation. The closer the surface temperature is to ambient temperature the harder it is to lose heat by conduction, convection, and radiation. In summer, the body surface temperature reached that threshold, but the core body temperature remained constant throughout the year for all bulls. Body surface temperature directly influences heat flow and the closer it is to the core body temperature the faster tends to be the heat loss from the core to the extremities (Randall et al., 2000). Angus presented higher respiratory rates, panting scores, and salivation than Crioulo Lageano bulls. In $14 \%$ of the collections, the respiratory rate in Angus bulls was above the reference value and sometimes open-mouth panting was observed, whereas in Crioulo Lageano this did not occur at any time. However, despite these differences both breeds were able to maintain a normal rectal temperature even during the hottest periods of the day. This indicates that breeds possibly use different mechanisms to increase thermolysis.

As well as physiological mechanisms, mammals also use behavioural and morphological changes to either accumulate or dissipate heat. The fact that Crioulo Lageano is a horned breed gives some information about the lower values found in the respiratory measurements in comparison with Angus bulls. In horned species that evolved to live in hotter environments, the vascularised inner core has a greater surface area than in temperate species, which contributes to a heat exchange process from the horns. McManus et al. $(2009 ; 2011)$ found that Crioula Lageano cattle were the best adapted naturalized breed among seven breeds studied, with traits such as hair length and number, sweat gland area and sweating rate among the most important in discriminating this breed from the others. Nevertheless, in winter, this characteristic may represent an important expenditure of energy (Picard et al., 1994). Taking this into account the Crioulo Lageano bulls did not need to increase heat loss by respiration as much as Angus and the dissipation of heat through the horn' surface is likely to have importance for their thermoregulation, as recognized in other horned ruminants.

Testicular thermoregulation is regulated by a complex of processes independently of core body temperature regulation (Kastelic et al., 1997). However, high environmental temperatures may affect proper thermoregulation and lead to a decrease in semen quality and even testicular degeneration (Newton et al., 2009). Scrotal surface temperatures in this study were constant across seasons in the afternoon. In winter, significant differences were found between breeds, with the lowest values for Crioulo Lageano bulls, but this was within the physiological range. Moreover, the topto-bottom temperature gradient of the scrotum was positive in both periods of the day and across the year, with the highest values in winter for Angus bulls (Table 4). These observations indicate that testicular thermoregulation of the bulls occurred normally in both seasons. Positive top-to-bottom gradients are expected under physiological conditions due to the temperature on the top of the scrotum, the closest point of the scrotum 
in relation to the body, must be higher than in the bottom of the scrotum. Statistical differences between breeds in the top-to-bottom gradients were only observed in winter, whilst in summer it remained unchanged. Nevertheless, the variation in Angus bulls was greater than in Crioulo Lageano bulls and is likely that for this reason no significant differences were found. Brito et al. (2004) also found a positive top-tobottom gradient in a study that included Bos indicus, crossbred and Bos taurus bulls, and the temperatures recorded from the top, middle and bottom of the scrotum differed among these three genetic groups.

Table 4. Mean \pm standard deviation of scrotal surface temperature $\left({ }^{\circ} \mathrm{C}\right)$ of Crioulo Lageano and Angus bulls in two seasons and periods of the day

\begin{tabular}{|c|c|c|c|c|c|}
\hline \multirow{2}{*}{\multicolumn{2}{|c|}{ Variable }} & \multicolumn{2}{|l|}{ Summer } & \multicolumn{2}{|c|}{ Winter } \\
\hline & & Angus & Crioulo Lageano & Angus & Crioulo Lageano \\
\hline & & \multicolumn{4}{|c|}{ Morning temperature $\left({ }^{\circ} \mathrm{C}\right)$} \\
\hline & maximum & $33.79 \pm 0.81 \mathrm{a}$ & $33.75 \pm 1.12 \mathrm{a}$ & $34.02 \pm 1.43 \mathrm{a}$ & $31.94 \pm 2.36 b$ \\
\hline \multirow[t]{3}{*}{ Top } & minimum & $32.43 \pm 0.93 \mathrm{a}$ & $32.67 \pm 1.2 \mathrm{a}$ & $31.12 \pm 2.27 \mathrm{a}$ & $27.03 \pm 3.38 b$ \\
\hline & average & $33.21 \pm 0.8 \mathrm{a}$ & $33.23 \pm 1.2 \mathrm{a}$ & $32.61 \pm 1.81 \mathrm{a}$ & $29.51 \pm 2.64 b$ \\
\hline & maximum & $32.11 \pm 1.18 \mathrm{a}$ & $31.66 \pm 1.6 \mathrm{a}$ & $27.41 \pm 2.19 b$ & $27.59 \pm 3.26 b$ \\
\hline \multirow[t]{2}{*}{ Bottom } & minimum & $30.88 \pm 1.32 \mathrm{a}$ & $30.19 \pm 1.87 \mathrm{a}$ & $22.76 \pm 3.45 b$ & $24.39 \pm 3.98 b$ \\
\hline & average & $31.52 \pm 1.24 \mathrm{a}$ & $30.93 \pm 1.64 \mathrm{a}$ & $25.37 \pm 2.09 b$ & $25.57 \pm 3.62 b$ \\
\hline \multirow{2}{*}{\multicolumn{2}{|c|}{ Top-to-bottom gradient }} & $1.71 \pm 1.21 \mathrm{c}$ & $2.3 \pm 0.94 \mathrm{c}$ & $7.24 \pm 3.22 \mathrm{a}$ & $3.92 \pm 1.47 \mathrm{~b}$ \\
\hline & & \multicolumn{4}{|c|}{ Afternoon temperature $\left({ }^{\circ} \mathrm{C}\right)$} \\
\hline \multirow[t]{3}{*}{ Top } & maximum & $34.68 \pm 0.98^{\mathrm{a}}$ & $34.44 \pm 1.45 \mathrm{a}$ & $34.53 \pm 0.79 \mathrm{a}$ & $33.18 \pm 1.77 b$ \\
\hline & minimum & $32.94 \pm 1.25^{\mathrm{a}}$ & $33.22 \pm 1.8 \mathrm{a}$ & $32.39 \pm 0.95 \mathrm{a}$ & $29.88 \pm 3.21 b$ \\
\hline & average & $33.99 \pm 1.09^{\mathrm{a}}$ & $33.86 \pm 1.63 \mathrm{a}$ & $33.45 \pm 0.82 \mathrm{a}$ & $31.55 \pm 2.54 b$ \\
\hline \multirow[t]{3}{*}{ Bottom } & maximum & $33.42 \pm 1.23^{\mathrm{a}}$ & $33.44 \pm 1.52 \mathrm{a}$ & $29.26 \pm 1.99 b$ & $29.78 \pm 2.89 b$ \\
\hline & minimum & $32.31 \pm 1.36^{\mathrm{a}}$ & $32.23 \pm 1.88 \mathrm{a}$ & $26.14 \pm 2.52 b$ & $27.6 \pm 3.31 b$ \\
\hline & average & $32.91 \pm 1.24^{\mathrm{a}}$ & $32.89 \pm 1.64 \mathrm{a}$ & $27.57 \pm 2.12 b$ & $28.55 \pm 3.13 b$ \\
\hline \multicolumn{2}{|c|}{ Top-to-bottom gradient } & $1.08 \pm 1.07 \mathrm{c}$ & $0.97 \pm 0.7 \mathrm{c}$ & $5.88 \pm 1.98 \mathrm{a}$ & $3.02 \pm 1.67 \mathrm{~b}$ \\
\hline
\end{tabular}

Notes: Top and bottom refer to head and tail of the surface of scrotum, respectively. Scrotal surface temperature was measured by infrared thermography. Means with different subscripts in the row are significantly different at $P<0.05$.

Significant differences were only seen in blood traits for rods, haemoglobin (HB) and haematocrit (HT) (Table 5). Angus bulls presented higher values for rods in summer in comparison with winter, whilst for Crioulo Lageano bulls it did not change significantly. $\mathrm{HB}$ and $\mathrm{HT}$ were significantly different in winter and the higher values were found in the Crioulo Lageano bulls. Despite this, they were within the reference values for cattle. 
Table 5. Complete blood count in Crioulo Lageano and Angus bulls in summer and in winter

\begin{tabular}{llllll}
\hline \multirow{2}{*}{ Variable } & Summer & & & Winter & \\
\cline { 2 - 3 } \cline { 5 - 6 } \cline { 5 - 6 } & Angus & Crioulo Lageano & & Angus & Crioulo \\
\hline WBC $\left(\times 10^{3} / \mu \mathrm{L}\right)$ & $10.27 \pm 2.97$ & $8.31 \pm 1.91$ & & $9.80 \pm 1.21$ & $9.40 \pm 2.49$ \\
Rods $\left(\times 10^{3} / \mu \mathrm{L}\right)$ & $0.36 \pm 0.21 \mathrm{a}$ & $0.26 \pm 0.12 \mathrm{ab}$ & & $0.08 \pm 0.07 \mathrm{c}$ & $0.14 \pm 0.11 \mathrm{bc}$ \\
Neut $\left(\times 10^{3} / \mu \mathrm{L}\right)$ & $3.22 \pm 0.88$ & $3.21 \pm 0.82$ & & $2.59 \pm 0.40$ & $2.77 \pm 0.85$ \\
Eosi $\left(\times 10^{3} / \mu \mathrm{L}\right)$ & $0.99 \pm 0.51$ & $0.68 \pm 0.36$ & & $1.25 \pm 0.47$ & $0.82 \pm 0.32$ \\
Lymph $\left(\times 10^{3} / \mu \mathrm{L}\right)$ & $4.89 \pm 2.54$ & $3.59 \pm 1.15$ & & $5.24 \pm 1.11$ & $4.99 \pm 2.06$ \\
Mono $\left(\times 10^{3} / \mu \mathrm{L}\right)$ & $0.81 \pm 0.36$ & $0.58 \pm 0.20$ & & $0.65 \pm 0.20$ & $0.68 \pm 0.30$ \\
RBC $\left(\times 10^{6} / \mu \mathrm{L}\right)$ & $7.27 \pm 0.75$ & $7.98 \pm 0.62$ & & $7.25 \pm 0.53$ & $8.00 \pm 0.75$ \\
HB $(\mathrm{g} / \mathrm{dL})$ & $12.77 \pm 1.31 \mathrm{ab}$ & $13.24 \pm 0.97 \mathrm{ab}$ & & $11.83 \pm 1.96 \mathrm{~b}$ & $13.86 \pm 0.68 \mathrm{a}$ \\
$\mathrm{HT}(\%)$ & $36.90 \pm 3.80 \mathrm{ab}$ & $38.59 \pm 2.88 \mathrm{a}$ & & $33.48 \pm 5.48 \mathrm{~b}$ & $39.55 \pm 2.02 \mathrm{a}$ \\
$\mathrm{MCV}(\mathrm{fL})$ & $51.01 \pm 4.92$ & $48.59 \pm 4.77$ & & $46.23 \pm 6.97$ & $49.63 \pm 2.78$ \\
$\mathrm{PLT}\left(\times 10^{6} / \mu \mathrm{L}\right)$ & $0.26 \pm 0.12$ & $0.24 \pm 0.14$ & & $0.30 \pm 0.13$ & $0.22 \pm 0.12$ \\
$\mathrm{~N} / \mathrm{L}$ & $0.75 \pm 0.28$ & $0.96 \pm 0.29$ & & $0.51 \pm 0.1$ & $0.54 \pm 0.18$ \\
\hline
\end{tabular}

WBC: white blood cell count, Neut: neutrophils, Eosi: eosinophils, Lymph: lymphocytes, Mono: monocytes, RBC: erythrocytes, HB: haemoglobin, HT: haematocrit, MCV: mean corpuscular volume, PLT: platelets, N/L: neutrophil: lymphocyte ratio.

Significant increases in $\mathrm{HB}$ and $\mathrm{HT}$ concentrations occur when the white blood cell count (WBC) and neutrophil count increase by two to three-fold, which characterizes a stress leukogram. In this study, the WBC remained within the normal values in both seasons. Another situation in that HT can raise is by splenic contraction and from RBC swelling that occurs after the sample is collected, but both cases are artefacts or errors (Weiss and Wardrop, 2010). In the white blood cell count, only rods increased significantly in summer. The absolute values of neutrophils and N/L were higher in summer than in winter, but without significant differences. These numeric changes were noted in all leukocyte values, but they were within the normal range for the species. The increase in RT accompanied by an increase in white blood cells may be explained because of the role of the immune system in protecting against environmental stressors. This relationship was also observed in sheep (McManus et al., 2009). When the environmental temperature becomes warmer, the rectal temperature tends to increase, and this induces physiological responses including secretion of catecholamines in an attempt to maintain core body temperature (Brenner et al., 1998). These hormones are released in the face of excitement, fear or any other stressful factor and incite demargination of neutrophils from the marginal pool into the circulating pool, which boosts the white blood cell count. In general, in an excitement leukogram, i.e., a 
physiological leukogram, mature neutrophils are the main cells observed and usually the counting return to normal values in up to 30 minutes after the stimuli. A different profile is observed in a stress leukogram, which is characterized by an increase of neutrophils $(\mathrm{N})$, decrease of lymphocytes (L) and eosinophils. In this experiment, the leukograms were similar to excitement rather than stress, but the mean values of the cell's categories remained within the reference values. Further, in bovines, a marked increase in the $\mathrm{N} / \mathrm{L}$ ratio, often greater than 1.0 , is observed in stress conditions (Weiss and Wardrop, 2010). In this study, some values for $\mathrm{N} / \mathrm{L}$ ratio were above 1.0 during summer, whilst in winter this did not occur. Nonetheless, the moderate stress in summer did was not enough to induce true stress found in a classic leukogram pattern, which includes neutrophilia, eosinopenia and lymphopenia.

Only variables that presented significant correlations and a coefficient magnitude above 0.3 will be discussed here. All environmental traits, except air humidity, presented high positive correlations with haematological traits (rods, neutrophils, mean corpuscular volume (MCV) and neutrophillymphocyte ratio), physiological responses (rectal temperature, respiratory rate and panting score), Benezra heat tolerance index and surface temperatures recorded by thermography (eye, body and scrotum). The positive correlation between rectal temperature (RT) and temperature and humidity index (THI) means that the bulls may not be able to maintain core body temperature due to the increase in environmental temperature and humidity. In a tropical country, no or negative correlation between RT and THI would be desirable to select animals for breeding programs, especially bulls that are exposed to harsh conditions during the breeding season. As well in this study, a positive correlation was observed in Holstein cows raised in a temperate region (Rejeb et al., 2009) and even in the tropically adapted breeds Curraleiro/Pé-Duro, Pantaneiro and Nelore cattle (Cardoso et al., 2016). These results lead us to assume to find a negative correlation between RT and THI is rare, at least in cattle.

Rectal temperature showed a positive correlation with rods, neutrophils and neutrophil-lymphocyte ratio (N/L) and was negatively correlated with haematocrit and haemoglobin. The increase of RT starts thermolysis mechanisms, such as evaporation ones, resulting in loss of body water. Depending on how much water is lost, changes in the haematocrit can be seen due to the haemoconcentration by dehydration, which was not the case herein (Thrall et al., 2007).

The increase in the rectal temperature also led to an increase in the respiratory rate, panting score, surface temperatures of the body, eye and scrotum, as well as for the Benezra Index. A positive correlation between the rectal temperature and respiratory rate was also observed in hair sheep (Correa et al., 2013). When bovines are in heat stress, respiration corresponds to up to $30 \%$ of the evaporative losses; the other $70 \%$ are due to cutaneous evaporation (Silva, 2000). In agreement with the present study, Daltro et al. (2017) found the rectal temperature positively correlated with the thermographic measurements in dairy cows. The peripheral 
vasodilatation is one of the key biophysical thermoregulatory mechanisms that transfer thermal energy from the internal organs to the skin in order to dissipate heat. This increases the surface temperature and, hence augments heat loss by conduction and convection (Silva, 2000).

In addition to the correlation with rectal temperature, there were also positive correlations between Benezra index with respiratory rate, panting score, surface temperatures measured by infrared thermography, rods, neutrophils, mean corpuscular volume (MCV) of erythrocytes, body weight, heart girth, chest depth and testicular volume. As mentioned, a Benezra index above 2 means heat discomfort and, in these circumstances, thermolysis mechanisms are readily activated. The positive relationship between the heat tolerance index and morphometric measurements was also reported in hair sheep in an experiment held in the Central-West Region of Brazil (Seixas et al., 2017). These correlations indicate that larger animals have poor adaptation to hot environments. Size of the animal is an important factor in heat flow, as larger animals have a relatively lower surface area to dissipate heat.

MCV showed a positive correlation with air temperature in both periods of the day. An adjustment in cell size is observed in response to environmental challenges, such as hypoxia or an increase in temperature. In this latter case, the oxygen demand increases due to the greater metabolic activity observed at higher temperatures which prompts an increase in the total volume of red blood cells to augment the delivery of oxygen to the tissues (Gillooly and Zenil-Ferguson, 2014).
Body and testicular measurements were positively correlated with MCV and negatively correlated with red blood cells counting (RBC). In other words, larger animals tend to have larger MCV and, due to larger cells naturally occupy more space, consequently, RBC will be lower. A moderated negative correlation between $\mathrm{MCV}$ and morphological measurements was also observed in Brazilian cattle (McManus et al., 2011). The size of blood cells may depend on body mass in mammals, but this is not the rule. Empirical knowledge for mammals supports the assumption of invariance of capillary size and flow rate, as well as, of the size of erythrocytes in relation to body mass (Savage et al., 2007). However, there is a lack of consensus about whether the number, size, and metabolic rate of cells change according to body size and the reason for this may be because measuring cell size is notably laborious (Kozłowski et al., 2010).

A partial least squares regression (PLS) was used in order to explore the influence of weather conditions and morphological traits on the physiological responses. After running PLS procedure several times, checking both VIP, coefficient value, and the $\mathrm{x} / \mathrm{y}$-scores plot, the variables that were considered to be more important in explaining the physiological responses of the animals in summer were the following: body weight, height at withers, heart girth, chest depth, testicular volume, skin thickness of the body, coat brightness, coat red colour intensity, yellow colour intensity of the hair and hair coat length; and in winter were the following: body length, heart girth, skin thickness of the body, hair coat density, hair coat length, maximum and minimum air temperature. 
For a good model, the first few factors must present a high correlation between the $x$ - and $y$-scores. Figure 2 shows the plot of $x$-scores versus $y$-scores obtained in this study, where a high correlation between the $\mathrm{x}$ - and $\mathrm{y}$-scores for the first and second factors can be seen and somewhat lower correlation for the third factor.

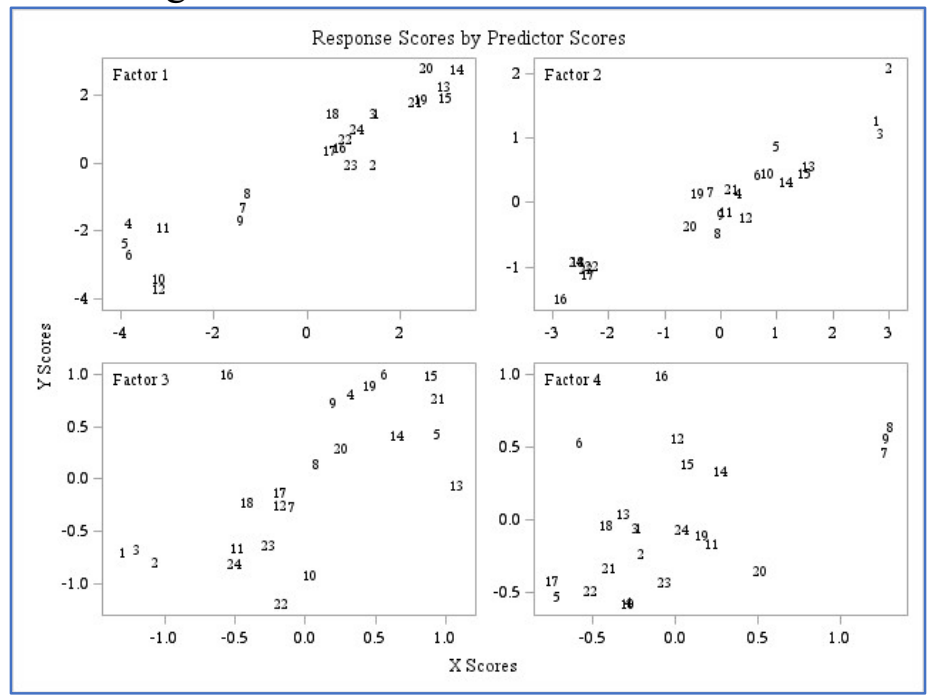

Figure 2. Plot of $x$ versus $y$-scores from partial least squares procedure

The first three factors explained the majority of the variance in summer and in winter (Table 7). In summer, these factors explained $94.58 \%$ of the variance in explanatory variables and $72.02 \%$ of the variance for dependent variables, while in winter was $79.89 \%$ and $71.35 \%$, respectively.

In summer, there was a high positive relationship among body and testicular measurements with MCV, hair length, Benezra Index and panting scores, whereas all these traits were negatively correlated with RBC, hair coat colour and somewhat lower correlated with skin thickness. All bulls presented highest Benezra Index in summer differing significantly from the index in winter. A high Benezra Index and fast panting indicate that an animal is less adapted (Benezra, 1954; Silva, 2000). In winter, coat colour was not important unlike in summer. Hair coat density and hair length were highly positive associated with each other and both were in the same direction than the cooler air temperatures recorded in the morning. The results for coat traits in winter are in agreement with others studies in cattle that found that coat and skin traits explained little variation in physiological parameters (McManus et al., 2011; Cardoso et al., 2016) but this is not true for summer in this study.

The positive relationship between physical traits and MCV found in summer could be explained by the following cascade of events. As mentioned above, larger animals are more vulnerable to heat stress, which causes hyperventilation - observed in this study - following by alkalosis respiratory status and an increase of stress hormones in circulation. Stress hormones, such as cortisol, stimulates reticulocytes releasing from the bone marrow reflecting on a high $\mathrm{MCV}$, as these cells are larger than mature 
erythrocytes (Weiss and Wardrop, 2010). In summary, on the one hand, in summer, a smaller animal, with light and short hair is better adapted to the region studied. It is known that body size is related to adaptation in different environments and can affect physiological traits and heat tolerance (Rojas-Downing et al., 2017). On the other hand, an animal with dense and long hair coat appears to be more desirable for the winter. In terms of coat characteristics, the Crioulo Lageano

bulls were seen to be better adapted to warm conditions while the Angus bulls are designed for cooler temperatures. Nevertheless, both breeds were able to maintain the body core temperature across the seasons, even experiencing moderate heat stress in summer.

\section{CONCLUSION}

Body size of the bulls was important for explaining physiological changes in both seasons, but their contribution was greater in summer than in winter. Hair coat characteristics favoured Crioulo Lageano in the summer and respiratory rate was likely to play an important role for thermoregulation in Angus. The bulls temporarily experienced moderate heat stress that prompted significant physiological changes, but they were less pronounced in Crioulo Lageano. Despite using different mechanisms for heat loss, it was clear that all bulls were able to maintain optimal testicular thermoregulation, as well as the body core temperature, throughout the seasons, showing good adaptation to the weather conditions in the Southern Brazil where the study was held.

\section{ACKNOWLEDGMENTS}

We acknowledge the Coordination for the Improvement of Higher Education Personnel (CAPES) and National Council for Scientific and Technological Development $(\mathrm{CNPq})$. We are also very grateful to the University of Edinburgh, Scotland's Rural College (SRUC) and The Roslin Institute, on behalf of Dr Joanne Conington, for all support throughout this paper's writing.

\section{REFERENCES}

ABREU, P.G., Abreu, V.M.N., Franciscon, L., COLDEBELLA, A., Amaral, A.G. 2012. Estimativa da temperatura de globo negro a partir da temperatura de bulbo seco. Engenharia Na AgriculturaVolume 19, 557-563

AKARACHANTACHOTE, N., Chadcham, S., Saithanu, K. 2014. Cutoff threshold of variable importance in projection for variable selection. International Journal of Pure and Applied Mathematics, 94, 307-322, 10.12732/ijdea.v12i1.823

BENEZRA MV 1954. A new index measuring the adaptability of cattle to tropical conditions. Journal Animal Science 13, 1015.

BERNABUCCI U, Lacetera N, Baumgard LH, Rhoads RP, Ronchi B and Nardone A 2010. Metabolic and hormonal acclimation to heat stress in domesticated ruminants. Animal 4, 1167-1183.

BISHOP-WILLIAMS KE, Berke O, Pearl DL, Hand K and Kelton DF 2015. Heat stress related dairy cow mortality during heat waves and control periods in rural Southern Ontario from 2010-2012. BMC veterinary research 11, 291. 
BRENNER I, Shek P, Zamecnik J and Shephard R 1998. Stress Hormones and the Immunological Responses to Heat and Exercise. International Journal of Sports Medicine 19, 130-143.

BRITO LFC, Silva AEDF, Barbosa RT and Kastelic JP 2004. Testicular thermoregulation in Bos indicus, crossbred and Bos taurus bulls: relationship with scrotal, testicular vascular cone and testicular morphology, and effects on semen quality and sperm production.

Theriogenology 61, 511-528.

CARDOSO CC, Lima FG, Fioravanti MCS, do Egito AA, e Silva FC de P, Tanure CB, Peripolli V and McManus C 2016. Heat tolerance in curraleiro pe-duro, pantaneiro and nelore cattle using thermographic images. Animals 6, 1-11.

CORREA MPC, Dallago BSL, Paiva SR, Canozzi MEA, Louvandini H, Barcellos JJ and McManus C 2013. Multivariate analysis of heat tolerance characteristics in Santa Inês and crossbred lambs in the Federal District of Brazil. Tropical Animal Health and Production 45, 1407-1414.

DALCIN VC, Fischer V, Daltro D dos S, Alfonzo EPM, Stumpf MT, Kolling GJ, Silva MVGB da, McManus C, Dalcin VC, Fischer V, Daltro D dos S, Alfonzo EPM, Stumpf MT, Kolling GJ, Silva MVGB da and McManus C 2016. Physiological parameters for thermal stress in dairy cattle. Revista Brasileira de Zootecnia 45, 458465.

DALTRO DS, Fischer V, Alfonzo EPM, Dalcin VC, Stumpf MT, Kolling GJ, da Silva MVGB and McManus C 2017. Infrared thermography as a method for evaluating the heat tolerance in dairy cows. Revista Brasileira de Zootecnia 46, 374 383. Environment Canada 2014.

Environment Canada's Wind Chill Index. Toronto.
FAO 2009. How to feed the world in 2050. In High-level expert forum, p. 35. Food and Agriculture Organization of the United Nations, Rome.

FAO 2015. Coping with climate change the roles of genetic resources for food and agriculture. Food and Agriculture Organization of the United Nations, Rome.

GILLOOLY JF and Zenil-Ferguson R 2014. Vertebrate blood cell volume increases with temperature: implications for aerobic activity. PeerJ 2.

KASTELIC JP, Byrne Cook R and Coulter GH 1997. Scrotal/testicular thermoregulation and the effects of increased testicular temperature in the bull. Veterinary Clinics of North America: Food Animal Practice 13, 271-282.

KERR S 2015. Livestock Heat Stress: Recognition, Response, and Prevention. Washington State University. Extension Fact Sheet FS157E, 1-10.

KOZŁOWSKI J, Czarnołe ، Ski M, Franç Ois-Krassowska A, Maciak S and Pis T 2010. Cell size is positively correlated between different tissues in passerine birds and amphibians, but not necessarily in mammals. Biology Letters 6, 792-796.

LCI. 1970: Patterns of transit losses. Livestock Conservation, Inc. Omaha, NE. Maia ASC, Silva RG and Loureiro CMB 2008. Latent heat loss of Holstein cows in a tropical environment: a prediction model.

Revista Brasileira de Zootecnia 37, 1837 1843.

MARIASEGARAM M, Chase CC, Chaparro JX, Olson TA, Brenneman RA and Niedz RP 2007. The slick hair coat locus maps to chromosome 20 in Senepolderived cattle. Animal Genetics 38, 54-59. 
MCMANUS CM, Faria DA, de Bem A, Maranhao AQ and Paiva SR 2020. Physiology and genetics of heat stress in cattle. CAB Reviews. 15, 018, pp 1-12

MCMANUS C, Castanheira M, Paiva SR, Louvandini H, Fioravanti MCS, Paludo GR, Bianchini E and Corrêa PS 2011. Use of multivariate analyses for determining heat tolerance in Brazilian cattle. Tropical Animal Health and Production 43, 623630 .

MCMANUS, C.; Prescott, E.; Paludo, G. R.; Bianchini, E.; Louvandini, H.; Mariante, A. S.; 2009. Heat tolerance in naturalized Brazilian cattle breeds. Livest. Sci. 120, 256-264

MCMANUS C, Paludo GR, Louvandini H, Gugel R, Sasaki LCB and Paiva SR 2009. Heat tolerance in Brazilian sheep: Physiological and blood parameters. Tropical Animal Health and Production 41, 95-101.

MENEGASSI SRO, Barcellos JOJ, Dias EA, Koetz C, Pereira GR, Peripolli V, McManus C, Canozzi MEA and Lopes FG 2015. Scrotal infrared digital thermography as a predictor of seasonal effects on sperm traits in Braford bulls. International Journal of Biometeorology 59, 357-364.

NEWTON LD, Kastelic JP, Wong B, van der Hoorn F and Thundathil J 2009. Elevated testicular temperature modulates expression patterns of sperm proteins in Holstein bulls. Molecular Reproduction and Development 76, 109-118.

PICARD K, Thomas DW, Festa-Bianchet $M$ and Lanthier C 1994. Bovid horns: an important site for heat loss during winter? Journal of Mammalogy 75, 710-713.

RANDALL D, Bruggren W, French K, Fernald R and Menezes CEL de 2000.
Usando a energia: enfrentando desafios ambientais. In Eckert fisiologia animal mecanismos e adaptações, pp. 619-673. Guanabara Koogan, Rio de Janeiro.

REECE WO, Erickson HH, Goff JP and Uemura EE 2015. Dukes' physiology of domestic animals. Wiley-Blackwell, Oxford, UK.

REJEB M, Sadraoui R, Najar T, Ben MM and Rejeb M 2009. A Complex Interrelationship between Rectal Temperature and Dairy Cows' Performance under Heat Stress Conditions. Open Journal of Animal Sciences 6, 24-30.

RENAUDEAU D, Collin A, Yahav S, de Basilio V, Gourdine JL and Collier RJ 2012. Adaptation to hot climate and strategies to alleviate heat stress in livestock production. Animal 6, 707-728.

ROJAS-DOWNING MM, Nejadhashemi AP, Harrigan T and Woznicki SA 2017. Climate change and livestock: Impacts, adaptation, and mitigation. Climate Risk Management 16, 145-163.

Savage VM, Allen AP, Brown JH, Gillooly JF, Herman AB, Woodruff WH and West GB 2007. Scaling of number, size, and metabolic rate of cells with body size in mammals. Proceedings of the National Academy of Sciences 104, 4718-4723.

Seixas L, De Melo CB, Tanure CB, Peripolli V and McManus C 2017. Heat tolerance in Brazilian hair sheep. AsianAustralasian Journal of Animal Sciences 30, 593-601.

\section{Silva RG 2000. Introdução à bioclimatologia animal. FAPESP, São Paulo.}

Silva RG and Maia ASC 2011. Evaporative cooling and cutaneous surface temperature of Holstein cows in tropical conditions. R.

Bras. Zootec 40, 1143-1147. 
Thrall MA, Baker DC, Campbell TW, DeNicola D and Fettman MJ 2007.

Hematologia e bioquímica clínica veterinária. Roca, São Paulo.

Tucker CB, Rogers AR, Verkerk GA, Kendall PE, Webster JR and Matthews LR 2007. Effects of shelter and body condition on the behaviour and physiology of dairy cattle in winter. Applied Animal

Behaviour Science 105, 1-13.

Usamentiaga R, Venegas $P$, Guerediaga J, Vega L, Molleda J, Bulnes FG. 2014.

Infrared thermography for temperature measurement and non-destructive testing. Sensors (Basel). 14, 12305-48. doi: 10.3390/s140712305.

Weiss DJ and Wardrop KJ 2010. Schalm's veterinary hematology. Wiley-Blackwell, Ames, Iowa, USA. 